\section{Expanding Research Triangle draws new land, new participants}

North Carolina

Glaxo, the British pharmaceutical company, has apparently discovered something North Carolina officials hope US companies will start discovering in greater numbers - the triangle of land that has the University of North Carolina, North Carolina State University and Duke University at its corners contains one of the highest concentrations of $\mathrm{PhD}$ scientists in the country.

This has made the region fertile ground for university, industry and government collaborations to turn academic brain power into high-technology products.

The proliferation of 'research parks' is a new phenomenon, but Research Triangle Park in North Carolina is now almost 30 years old. It has been through some ups and downs as political currents have shifted (see below) but now contains 54 companies and government agencies, including Burroughs Wellcome, IBM and Northern Telecom, all within a 15-minute journey of the three universities. And although the park is the largest in the world it is still growing - a new southern zone will bring the park's area to 6,700 acres.

New companies are still coming to the park and new kinds of associations are being formed among the three local universities, industry and government. At the University of North Carolina (UNC) at Chapel Hill, the pharmaceutical company Glaxo has entered into a unique arrangement that will allow university scientists and Glaxo researchers to share a \$3million research facility.

The institute is the brainchild of Glaxo's research director Pedro Cuatrecasas. After moving from Burroughs Wellcome, he wanted to build up a solid research team quickly, without waiting for Glaxo's massive new US headquarters to be completed in the park. Instead of opting for a temporary laboratory, Cuatrecasas approached UNC-Chapel Hill with an offer to build a research laboratory on campus that would revert to the university at the end of five years, or whenever

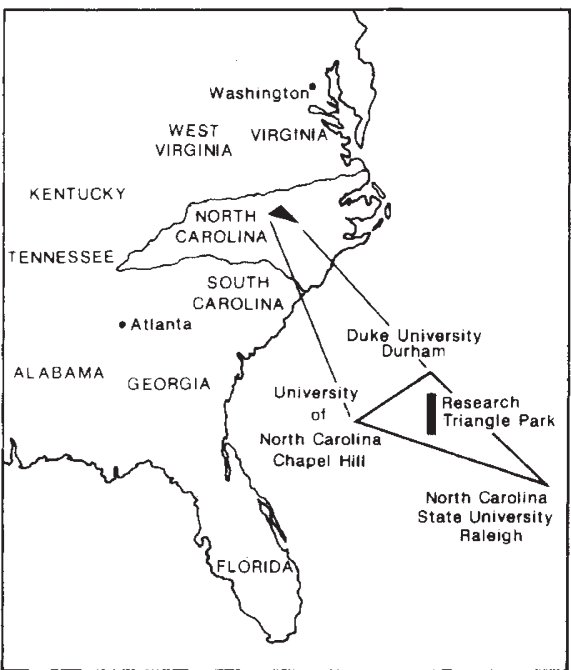

Glaxo's headquarters was finished.

Research will centre on cancer and viral diseases, AIDS (acquired immune deficiency syndrome) and molecular genetics - "very similar to the kinds of research already going on at UNC...but more focused on the use of new chemicals and organic chemicals", says Cuatrecasas. There will be no restrictions on the publication of research performed in the facility, and Cuatrecasas says that "it's possible we will make mistakes" in not retaining property rights over substances developed

\section{Thirty years of Research Triangle Park \\ North Carolina \\ was Chemstrand, later to become}

THE decision to create the Research Triangle Park in 1957 was prompted by a state-wide study to find ways to broaden North Carolina's tax base and to staunch the 'brain-drain' of promising young scientists graduating from the local universities and leaving the state. The state sought to lure chemical, pharmaceutical and electronics companies to the area, and local faculty called on corporate executives to sing North Carolina's praises.

In the autumn of $1958, \$ 1.5$ million was raised in 60 days, $\$ 1$ million towards the development of the property and the rest towards the foundation of Research Triangle Institute, a private research institute set up to do contract research.

The first company to build in the park Monsanto, in 1959. Smaller companies began to trickle in, but North Carolina's racial problems in the early 1960 s kept companies from investing in the area.

The next major coup for the park came when former state governor Luther Hodges, then US Secretary of Commerce, persuaded the president of IBM to take a look at the area. IBM built a research facility in the park in 1965 , the same year the US National Institute of Environmental Health Sciences was located there, and Research Triangle Park was on its way.

In recent years, the US headquarters of Burroughs Wellcome has been built in the park, and Glaxo is building an extensive facility there at its headquarters, expected to be completed in 1991 . there. But no drug development will occur in the building, and he says the risks of losing exclusive rights over new substances are more than compensated for by the ability to conduct research in an environment that promotes the free exchange of ideas and mutual trust. Glaxo scientists will hold teaching posts at the university.

Cuatrecasas believes that the exposure of university scientists and students to people who are actively pursuing therapies will give them a better perspective on their own research, and possibly make them aware of alternative career paths.

Over at North Carolina State University, the university is celebrating its hundredth birthday by building a new research campus where academic and industrial scientists can work together. The first building is nearly complete on a 780 -acre site granted by the state. Research will be concentrated in traditional strengths: textiles, engineering, and agricultural and forestry biotechnology. Included will be a conference centre and hotel, residences for visiting scientists, and $85,000-1,150,000$ square feet of office space. Part of the space will provide 'incubators' for new companies intending to exploit technology developed on campus.

Development funds will come from the state and through bond issues, but Philip Carter, associate vice-chancellor for research, says the university will also take a "let's make a deal" approach in accepting offers from companies wishing to finance a research facility. Many of the projects undertaken on the campus will bridge the gap between basic and applied research, and cut across traditional disciplinary boundaries. The nearly completed 30,000-square-foot engineering building will house research on precision engineering and semiconductors, with 5,000 square feet of space reserved for industrial partners. A similar life-sciences building will be constructed next, with an emphasis on biotechnology.

Much of the 'incubator' space will be partially funded by the North Carolina Biotechnology Center, set up to boost biotechnology in the state. A total of $\$ 6.5$ million will be given this year to academic researchers and to help new companies get on their feet. Among the companies set up in the centre's six-year history is Embrex, Inc., a poultry biotechnology company started in 1985 using technology licensed from the US Department of Agriculture. The company has developed an injector that should make it possible to replace the costly business of vaccinating hatchlings against the poultry disease coccidiosis with automatic vaccination of embryos in the egg.

Carol Ezzell

\section{NIH budget: correction}

The budget of the US National Institutes of Health (Nature 329, 573; 1987) is $\$ 6,200$ million. 